\title{
Portfolio Cleaning of Problem Project Loans in Hungary - Experiences Related to the Systemic Risk Buffer, as a Targeted Macroprudential Instrument*
}

\author{
Péter Fáykiss - Erzsébet-Judit Rariga - Márton Zsigó
}

After the crisis, more than 50 per cent of project exposures related to real estate financing became problem exposures at the largest Hungarian banking groups. With a view to managing macroprudential risks, the Magyar Nemzeti Bank introduced a systemic risk buffer, the rate of which has been calibrated in proportion to the individual contribution to systemic risk. In this paper, based on the data available in the project exposure database at contractual granularity, we analyse certain characteristics of these transactions in the third quarter of 2015, immediately prior the announcement of the capital buffer requirement, as well as the adjustment by the institutions until the end of the first quarter of 2017, i.e. the start date of the mandatory recognition of the capital buffer. We found that banks typically cleaned the larger problem exposures, and there is no indication that institutions gave preference in the cleaning process to problem exposures that defaulted more recently. In fact, when examining the institutions preliminarily affected by the announcement about the intended capital buffer quite the opposite was seen. The analysis also revealed that cleaning was stronger at those institutions which, based on the 2015 Q3 data, would have been preliminarily affected by the systemic risk buffer.

Journal of Economic Literature (JEL) codes: G21, G28, G32, G33

Keywords: real estate financing, non-performing loans, macroprudential policy, financial stability, portfolio cleaning, systemic risk

\section{Introduction}

After the outbreak of the financial crisis, a large portfolio of non-performing loans built up in certain countries' banking sectors. In Hungary, this was primarily observed in relation to households' foreign currency loans; however, the portfolio

* The papers in this issue contain the views of the authors which are not necessarily the same as the official views of the Magyar Nemzeti Bank.

Péter Fáykiss is a Director at the Magyar Nemzeti Bank. Email: faykissp@mnb.hu

Erzsébet-Judit Rariga is an Economic Analyst at the Magyar Nemzeti Bank. Email: rarigaj@mnb.hu

Márton Zsigó is an Analyst at the Magyar Nemzeti Bank. Email: zsigoma@mnb.hu

The Hungarian manuscript was received on 20 December 2018.

DOI: http://doi.org/10.33893/FER.18.3.5282 
of non-performing project loans - particularly of loans secured by commercial real estate $^{1}$ - also started to rise steeply. At the largest banking groups in Hungary, more than 50 per cent of project exposures, most of which were related to real estate financing, became non-performing (Szenes et al. 2017).

In addition to the large size of the non-performing portfolios, the slow cleaning of these portfolios caused problems throughout Europe. While in the United States the ratio of non-performing loans already started to decrease gradually from $2010,{ }^{2}$ in the EU a moderate decline in such loans was only observed starting from mid-2014. Moreover, the outstanding level is still relatively high, at around 7-8 per cent across the $\mathrm{EU}$, and the related risks have been assessed as being substantial by several EU institutions and authorities of the Member States (e.g. ESRB 2017, EP 2017, EC 2017, or for the measures taken by the Member States see ECB 2017).

The Magyar Nemzeti Bank (MNB) also deemed the persistently large portfolio and institutional concentration of the problem project loans observed in the Hungarian banking sector to be a key macroprudential risk. In order to manage this risk, the MNB opted to introduce the systemic risk buffer (SRB) (see e.g. MNB 2015), with buffer rates determined in proportion to the individual contribution to the systemic risk. ${ }^{3}$ The systemic risk buffers applicable to the individual institutions were prescribed in the form of individual MNB decisions, and banks had to comply with the new macroprudential capital buffer requirements starting from 1 July 2017. Thus, the respective market participants had a relatively long adjustment period to clean the problem project exposures or - if portfolio cleaning failed - to build up their capital buffer. In this paper, we analyse the effects of this macroprudential intervention based on micro data originating from the regulator, the MNB, with special attention to the time profile and composition of the portfolio cleaning which occurred.

This paper is structured as follows: After the introduction, we review the potential unfavourable effects of the large non-performing portfolio on the banking sector and the real economy, also touching on the potentially insufficient motivation of the

\footnotetext{
${ }^{1}$ Commercial real estate loans/project loans include the exposures where the primary source of repayment of the loan is represented by the cash flow generated by the utilisation of the real estate (sales, lease, facility management).

${ }^{2}$ The faster decline observed in the United States was attributable to a number of factors (for an overview of this see e.g. Baudino - Yun 2017), including, among other things, the commonly applied securitisation of loans, the size, activity and development level of the loan exposures' secondary markets and investors, the more prepared legislative and regulatory environment (e.g. extremely efficient out-of-court debt settlement procedures, stricter loss recognition rules, stipulating a shorter timeframe than the European regulation), and the special government programmes (e.g. the well-known Troubled Asset Relief Programme, or the Public-Private Investment Program built on a combination of public and private capital). In the period under review, these credit and capital market conditions, and the legislative and regulatory tools that were available in the United States during the financial crisis, as well as the government programmes (which may require substantial room for fiscal manoeuvre), were typically not available or were much more limited in the European markets and regulatory environment to support the cleaning the problem loan portfolios.

${ }^{3}$ For more details, see Section 4.2.
} 
banking sector to clean the portfolio in timely manner. Then we briefly present the characteristics of the non-performing project loan portfolio secured by commercial real estate which is regarded as systemically risky, both in terms of the type of the collateral real estate, denomination of the loans and the cash flow generation capacity of the scheme. Section 4 describes the details of the introduction of the macroprudential measure, i.e. the systemic risk buffer, applied for the management of the systemic risk related to project loans secured by commercial real estate, and then Section 5 presents the adjustment by credit institutions, observed following announcement of the measure. Finally, we summarise the key conclusions of the paper.

\section{Theoretical overview: Unfavourable effects of the large non- performing portfolio on the banking sector and the real economy}

\subsection{Consequences of the excessive build-up and persistent presence of the problem loan portfolio}

The extensive accumulation and long-term presence of non-performing exposures in the balance sheet of the banking sector can have an unfavourable effect on financial stability and healthy lending. In the wake of financial crises that typically occur after assuming excessive credit risk, the volume of non-performing or problem credit exposures can inflate in the balance sheets of credit institutions to an extraordinary degree. If this affects a large range of institutions in the banking sector, it can jeopardise financial stability and be detrimental to the respective banks' lending activity, credit allocation decisions and efficient operation. The negative consequences of this may appear in macroeconomic performance (Aiyar et al. 2015, Balgova et al. 2016, Berti et al. 2017, EC 2017, Suárez - Serrano 2018). Construction and real estate development may prove to be particularly vulnerable to a sharp rise in the banking sector's non-performing ratio (as implied by the analysis of Ghosh 2017), while borrowers may also experience it directly, e.g. through higher interest rate spreads.

Due to the limited information, market valuation of portfolio quality and the nonperforming loans may be difficult, and consequently a high ratio of such loans weakens investor confidence in the institutions in question. The typically low transparency renders the assessment of the fair value and the risk associated with the non-performing loans problematic, and this market imperfection may also be compounded by the possible intention of the bank's management to temporarily conceal the problems. ${ }^{4} \mathrm{~A}$ large problem portfolio can significantly undermine

\footnotetext{
${ }^{4}$ For the information problems with the valuation of problem loans and the hypotheses related to the motivations aimed at the maintenance of this, see Fell et al. (2017) and Baudino - Yun (2017), while for the problem of the bank's private information, learnt upon lending but difficult to share, and for the relation between the generation of the narrowing credit risk information and the (over)valuation of the real estate collateral, see Asriyan et al. (2018).
} 
investors' and depositors' perception of the bank's risk. As a result, the affected institutions' access to capital and money markets becomes more expensive and they may operate only with higher cost of finance (Aiyar et al. 2015, Balgova et al. 2016, Berti et al. 2017 and Suárez - Serrano 2018). At the same time, the deterioration in financing conditions may be unequal; it may have stronger effect on institutions that became financially weaker during the stress period or operate with low profitability, while the deterioration may be moderate at institutions which remain more stable and profitable, even if they operate with relatively higher non-performing exposure ratio (Angelini 2018).

A large non-performing loan portfolio can also erode the profitability of the affected bank. Since no income is typically realised on problem loan exposures or is only realised at substantially lower rate, while the costs of finance are higher due to the higher regulatory capital and provisioning requirements and higher risk spreads, large non-performing portfolios can result in a significant deterioration in profitability. For example, according to the simulation performed by the European Central Bank, replacement of the non-performing loans over a period of three years after 2016 would have improved the return on equity by 1 percentage point on average, and by $2.5-5$ percentage points in certain Member States involved in the analysis (Constâncio 2017).

The deteriorating portfolio quality and the substantially weakened profitability and capitalisation level may have unfavourable effect on the banks' willingness to take risks. The deteriorating portfolio quality may limit risk-taking capacity and prompt banks to act cautiously. By contrast, willingness to take risks may be influenced in the opposite direction (which may also lead to systemic risks), if - due to the bank's losses leverage increases - the owners' skin in the game decreases and moral hazard mechanisms ${ }^{5}$ begin to take effect. This may push the affected banks to follow a higher risk strategy based on the uncertain recovery of non-performing loans. This is because compared to the outcome of recovery - which has a low probability, but offers high payment - a large part of the potential costs must be borne by the external financing entities, and thus the owners and/or management may be more willing to risk the bank's profitable operation or even take a gamble on a resurrection strategy. Empirical analysis should be performed in order to decide which of the two effects in the opposite directions dominates risk-taking (for more details on this, see e.g. Kirti 2017, Dinger - Vallascas 2016).

For banks operating with lower profitability and a more unstable financial position, it may be difficult to expand their lending via the financing of productive real economy investment opportunities. Earlier empirical research ${ }^{6}$ concludes that - both in the

\footnotetext{
${ }^{5}$ The theoretical mechanisms are described in the summary note of Stolz (2002), while for the empirical analysis, see e.g. the paper of Gropp and Vesala (2004).

${ }^{6}$ See Bending et al. (2014), and the studies mentioned in the first paragraph of this sub-section.
} 
euro area and in the countries of the Central-Eastern European (CEE) region - with regard to banks operating with higher non-performing portfolios the large portfolio and rapid rise in problem exposures typically correlates with more moderate growth in the outstanding lending, which may be particularly unfavourable for industries that generally rely on bank financing or for small and medium-sized enterprises (Aiyar et al. 2015). One issue which still awaits further underpinning of empirical research is the question of through which theoretical channels the effect between the high non-performing portfolios and the lending activity, as well as the interest rate spread on loans materialises, where the latter, in theory, may also influence the operation of monetary policy transmission. Even when controlling for the banks' regulatory capital position, certain analyses indicate that a rise in the ratio of problem portfolios may have unfavourable effect on credit supply (see e.g. Bredl 2017). At the same time, Accornero et al. (2017), when examining the Italian economy under deteriorated capitalisation and losses resulting from problem exposure, estimated a negative impact of corporate credit demand decline in the weakening of lending activity, presumably due to e.g. the worsening risk characteristics and investment opportunities of borrowers.

The long-term maintenance of problem loans may distort optimal credit allocation, while cleaning may reduce borrowers' debt overhang. The long-term maintenance of a high non-performing ratio in the banking sector entails the risk that "zombie" lending may appear between banks and their corporate clients. This usually characterises vulnerable banks operating with low capitalisation, the major part of the lending capacity of which may be absorbed by financing the less productive activity of corporate clients struggling with financial difficulties, which offers low return (Gandrud - Hallerberg 2017). Among the corporations financed in this way, the availability of zombie loans enforces neither the cleaning of the market nor deleveraging by corporations, and excessive debt financing is expensive, while no tangible restructuring takes place. Excessive indebtedness of corporations - but also of households - may reduce the capital invested in productive investments; e.g. the outstanding, long-term debt servicing may represent excessive burden on investors' anticipated return and makes additional fund raising more difficult (see e.g. Philippon 2009 or Occhino 2010). Storz et al. (2017) attributed the appearance of "zombification" in the periphery economies of the euro area to the more vulnerable corporate clients who were able to increase their indebtedness further between 2010 and 2014, typically thorough their ailing banks.

The efficiency of the banking sector's operation and the accumulation of extraordinarily large non-performing portfolio may be interrelated. On the one hand, the management of problem portfolios may absorb major organisational resources. In normal periods, the development of activities dedicated to the management of extraordinary volumes of non-performing loans is not part of banks' 
operation. An example of this may be when the banking staff is engaged in workout activity rather than in lending, or the management is occupied with the sales of collateral. The organisational development of this may also significantly undermine a bank's profitability and efficient operation (as implied e.g. by the analysis of Berger - Young 1995, where examining the banks of the United States they found that there is Granger causality between the high level of non-performing loans and the deterioration in cost efficiency, which - according to their hypothesis - may be caused by the rise in administrative and operational costs). On the other hand, investors may interpret the high non-performing ratio as lack of efficient operation, risk management and management. ${ }^{7}$

The permanent presence of non-performing debtors in the financial system may erode the willingness of more and more clients to pay and trigger additional nonperformance. The preparedness of the credit institutions with a large volume of non-performing loans for the workload and the special capacities and resources necessary to carry this out may be limited. Based on the large number of former non-performers, customers may get the impression that the probability of the lender's sanctioning non-performance is low, and thus they may be more inclined to opt for strategic non-performance (i.e. they perform below their repayment capacity, if this is a more profitable option for them compared to duly performing and maintaining the customer relationship developed with the bank). Having examined the Italian banking system, Schiantarelli et al. (2016) found that debtors - convinced of their stronger bargaining position and seeing the steep rise in past non-performances - run on banks of less stable financial situation (borrowers run), i.e. they opt for strategic non-performance in large numbers.

Excessively fast scheduling of portfolio cleaning may also lead to substantial, systemic problems. The abrupt or almost simultaneous derecognition of problem exposures among the credit institutions involved and the excessively strong incentives included in the related regulations may also divert the cleaning process from optimal scheduling. Wide-scale, abrupt cleaning may confront institutions which are already struggling with a weakened financial position with major losses, as a result of assets sales or the realisation of collateral in large quantities. The losses thus generated may also give rise to an involuntary contraction of lending activity and to a change in the bank's risk appetite. Furthermore, pressing too much for cleaning may entail the termination of valuable customer relations and interrupt the financing of corporations which are struggling with temporary financial difficulties, but operate with favourable productivity in the long run (Angelini 2018).

\footnotetext{
${ }^{7}$ The hypotheses relate to the interactions of efficiency and non-performing ratio are examined by Louzis et al. (2012); Tarchouna et al. (2017) deals with the impact of corporate governance on the development of non-performing portfolios, while all of this is brought into connection with market and investor expectations by Bredl (2017).
} 


\subsection{Potentially insufficient motivation of the banking sector to clean the portfolio}

The financial incentives of banks for the adequate - i.e. optimal for the functioning of the economy as a whole - reduction of the high ratio of problem exposures may prove to be insufficient. Banks may not take into consideration the costs presented in the previous subsection when making their business decisions, such as postponing balance sheet cleaning and the deterioration in efficient operation. When examining the life cycle of non-performing loans (see Suárez - Serrano 2018), we found that the bank's management may be interested in delaying the timely recognition of non-performance (Szenes et al. 2017), fearing that the assessment of the management's performance may be more strongly prejudiced if the bank recognises the individual loan repayment problems and the deterioration in loan portfolio quality before those become obvious across the sector and at the competitors as well. As a result of this, during an economic recession and in financial stress periods, the materialisation of credit risk problems may occur en masse, with a delay and simultaneously at several institutions, which may further deepen the crisis processes, e.g. the contraction in lending. ${ }^{8}$

Typically, more vulnerable banks may try to conceal their customers' debt repayment problems over the long run by renewing the loans granted to customers with poor solvency or by restructuring them ("evergreening"), which offers no real solution. In parallel with the deterioration in customers' solvency, certain lenders may permanently settle on the financing of problem corporations, and thus roll over the loans under preferential conditions which are tailored to decreased debt servicing capacity. One reason for this could be the permanent postponement of the recognition of major losses, e.g. due to the banks' remuneration systems, while maintaining the bank's own solvency may also depend on keeping its customers financially alive (Peek - Rosengren 2005, Homar et al. 2015).

The information problems of secondary markets, the special features of the demand side and simultaneous sales of large volumes may reduce the return realisable on the sales of problem exposures. Selling the portfolio to secondary market participants specialised in the management of those is an essential tool of portfolio cleaning. However, on these markets it may be typical that buyers purchase the respective loans with a major information deficit (Navaretti et al. 2017). As a result of this, credit institutions are able to sell the problem assets only at a price that does not fully reflect the real, more favourable quality of the assets. Moreover, the limited size and trading flow of secondary markets, the heterogeneity of the sold exposures, the institutional structure of the demand side (e.g. quasi-monopsonistic, or just the opposite operating with fragmented capacities) may create additional

\footnotetext{
${ }^{8}$ For details on the systemic effects see Bushman - Williams (2015); the hypotheses related to the underlying mechanisms are summarised by $L i(2017)$.
} 
obstacles to price discovery or improvement in supply side return. All of these factors reduce the opportunity cost of keeping the problem exposures in the balance sheet and hits those who take action first ("first mover disadvantage"). Almost simultaneous, mass sales may entail a major decrease in prices, similarly to the situation after the mass realisation of collaterals, which may also discourage certain institutions.

Banks may also be hindered in the cleaning by their weakened financial position. The financial stress characterising periods when problem exposures accumulate in large volumes may erode credit institutions' profitability and capital position. Moreover, undertaking excessive credit risk may strengthen cyclically in the banking sector and procyclical underprovisioning may arise. ${ }^{9}$ As a result of the foregoing, the increase in defaults in the recessionary phase of the credit cycle may take them by surprise, and they may take efforts to postpone the losses and writeoffs accompanying cleaning while they have weakened capitalisation (this may be encouraged by avoiding the breach of regulatory requirements, and also by the intention to avoid the development of negative market perception of the bank or the incentives for income smoothing [Bethlendi 2007]).

The accounting, taxation and prudential framework and other institutional factors may also have major impact on the banking sector's decision related to portfolio cleaning. The banks' decisions related to the management of non-performing loans may be distorted by accounting rules, which for example permit the recognition of interest income in respect of such exposures. Under the IFRS 9 international financial reporting standard, in the European banking systems accrued interest receivable may be recognised for the net amount of the problem exposures, contrary to the FASB approach used in the United States. The IFRS 9, and the preceding IAS 39 rules may distort net interest income, the solvency capital and impairment rate as well, and encourage banks to postpone the recognition of losses (IMF 2015, Jassaud - Kang 2015, Cohen - Edwards 2017, Baudino et al. 2018). By contrast, in the period under review, the special Hungarian regulation prescribed the suspension of interest-type incomes in the event of delinquency of 30 days or more, where although it did not mean the requirement to classify the loan as non-performing automatically - the suspended interest and commission could not be recognised as receivable and income, and no provision and impairment could be recognised in respect of them either. ${ }^{10}$ Further examples include the accounting and prudential rules prescribing loan loss provisioning and solvency capital accumulation, which since selling the non-performing loans reveals the realised losses - confronts bank with stricter requirements and additional provisioning or capital requirements (Fell

\footnotetext{
${ }^{9}$ See e.g. Olszak et al. (2017), and the findings of Szenes et al. (2017) on the problem of cyclicity in risk management and regulation.

${ }^{10}$ See Section 17 of Government Decree 250/2000 (XII. 24) on the annual reporting and bookkeeping obligations of credit institutions and financial enterprises.
} 
et al. 2016, Gangeri et al. 2017). The tax regulations may permit that - prior to the derecognition of the non-performing exposure - even partial loan loss provisions can be recognised as deductible expenses. The financial expenses, the time required and the uncertainty of the legal institutions and legal procedures, as well as certain limitations of the status of European harmonisation and transparency - e.g. the elaboration of bankruptcy laws and efficiency of foreclosure - may also influence banks' strategy in the management of non-performing portfolios (for more details on these issues, see Aiyar et al. 2015, Suárez - Serrano 2018).

\section{The large non-performing portfolio of project loans secured by commercial real estate as a systemic risk}

In the pre-crisis period, project loans - particularly those secured by commercial real estate (CRE) - expanded dynamically. In 2008 alone, disbursement amounted to roughly HUF 600 billion annually, while the portfolio outstanding in the initial period of the crisis was close to HUF 2,800 billion. Moreover, this portfolio was concentrated to a great degree: the vast majority of the project loans secured by commercial real estate were in the books of a few Hungarian complex banking groups (MNB 2015, Szenes et al. 2017).

Following the dynamic increase, after the outbreak of the crisis disbursements of project loans secured by CRE declined substantially. While during 2008, the volume of loans placed quarterly in this segment typically amounted to HUF 120-160 billion, from 2010/2011 this declined to an amount of roughly HUF 20-60 billion (Figure 1). In parallel with this, the non-performing portfolio also started to rise steeply, as the ratio of loans non-performing for more than 90 days rose to above 18 per cent by 2012 from around 4 per cent registered in 2008. This ratio was even higher for project loans: roughly 50 per cent of the project loans secured by commercial real estate became non-performing later on, based on which it can be stated that after the retail foreign currency loans the banking sector realised the largest losses on this portfolio (Szenes et al. 2017). 


\section{Figure 1}

Ratio and volume of non-performing corporate loans in the credit institution sector

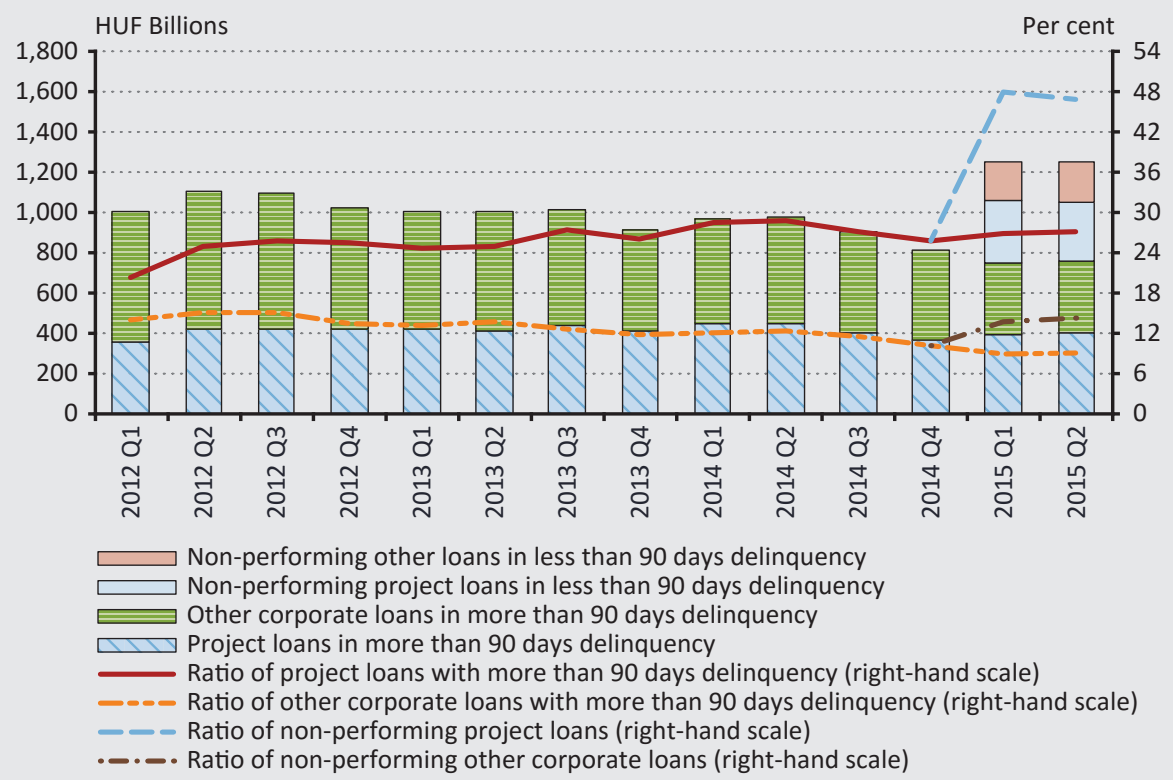

The ratio of problem loans was much higher within the project loans, and typically within those secured by commercial real estate, than within other corporate loans. It is worth briefly reviewing the reasons that gave rise to such a high ratio of nonperforming loans in this segment:

- Typically, the most important factor for project loans is the earnings potential of the respective project, since this is the primary source of loan repayment. However, for project loans secured by CRE the earnings potential is extremely vulnerable to economic cycles, since in the case of offices, shopping malls, hotels, etc. a drastic deterioration in macroeconomic variables substantially lowers the profitability of these sectors via the decline in aggregate demand, and thus cyclical effects strengthen (ESRB 2015).

- Beyond the significant sensitivity of the segment to cycles, the practice of excessive leverage also increased risks. Low own contribution was typical for project loans secured by commercial property and in the case of building site financing practically only the minimum own contribution was available (Szenes et al. 2017). This did not improve the shock absorbing capacity of the project, nor did it strengthen borrowers' willingness to cooperate (the "moral hazard" problem). 
- Project loans secured by commercial real estate were typically denominated in foreign currency, and thus - in addition to changes in the business cycles unfavourable trends in foreign exchange rates also had a negative impact on the portfolio. Although in several cases in these transactions not only the financing, but also the rents were often denominated in foreign currency, this often represented only a virtual hedge for changes in foreign exchange rates, since the real income of lessees, e.g. a shopping mall, was realised in local currency, i.e. in forint (Szenes et al. 2017).

In its publication dated 18 November 2015, ${ }^{11}$ the MNB assessed the persistently large portfolio and the institutional concentration of problem project loans observed in the Hungarian banking sector as a key macroprudential risk. Although in a lower proportion the presence of non-performing loan portfolios can be regarded as a natural attribute of banking operations, their excessively fast growth and the persistence of problem portfolios - as seen in the previous section - carry severe financial stability and macroprudential risks.

At the same time, with a view to managing the risk, the MNB opted for the introduction of the system risk buffer, the rate of which is determined as a proportion of the individual contribution to the systemic risk. The MNB prescribed the systemic risk buffer at the institutional level at a rate between 0 and 2 per cent of the domestic risk weighted total exposure amount, and at consolidated level, it must be met with CET1 capital elements in addition to the other capital buffers. The systemic risk buffers related to the individual institutions were prescribed in the form of individual MNB decisions, and based on the MNB's communication, banks had to comply with the new macroprudential capital buffer requirement initially from 1 January 2017, which later was changed 1 July 2017. Thus, the respective market participants had a relatively long adjustment period to clean the problem project exposures or, if the portfolio cleaning failed, to recognise the capital buffer. In the following section we briefly present the features of the affected problem project loan portfolio directly prior to the announcement. The analysis was performed on the basis of the portfolios outstanding at the end of 2015 Q3.

Based on the utilised micro-level, fairly detailed MNB database (data supply L70), containing more than 720 individual problem transactions of the banking sector, we found that half of the problem project loans - i.e. restructured or already nonperforming - secured by commercial real estate, outstanding on 30 September 2015, were non-performing for more than 90 days (Figure 2). The portfolio not yet overdue but based on the respective bank's assessment likely to become nonperforming, amounted to 4 per cent, while further 13 per cent included repossessed

${ }_{11}$ https://www.mnb.hu/sajtoszoba/sajtokozlemenyek/2015-evi-sajtokozlemenyek/a-problemasprojekthitelekbol-eredo-kockazatok-kezelesere-az-mnb-rendszerkockazati-tokepuffert-vezet-be 
real estate stated in the banks' balance sheet. The latter case means that certain banks tried to manage part of the long-time non-performing loans by taking the commercial real estate offered as collateral for the project loan on their balance sheet, thereby reducing the problem project loan exposure. After this, the real estate project was managed by the bank - either directly, or through a facility management company (according to the Hungarian regulations, such real estate may burden the banks' balance sheet only for a relatively short time, and thus these institutions must sell them within a few years). The restructured, but not yet problem-free project loans accounting for the remaining part, i.e. roughly one-third, of the problem portfolio. These included transactions that have already been restructured, but the period after which they can be reported as problemfree has not yet elapsed. Here the transactions restructured into bullet or balloon loans (or were such loans from the outset but were once again restructured) - i.e. the principal debt must be paid in lump sum only at the end of the repayment period, and until then the project makes only interest instalments - deserve special attention. Within these schemes it is a major problem that by repeatedly prolonging the end of the repayment period, evergreen transactions are essentially created in such cases when the project in fact is no longer able to generate the cash flow of the respective loan.

\section{Figure 2}

Distribution of restructured, non-performing project loans secured by commercial real estate and real estate exposures within the problem portfolio (30 September 2015)

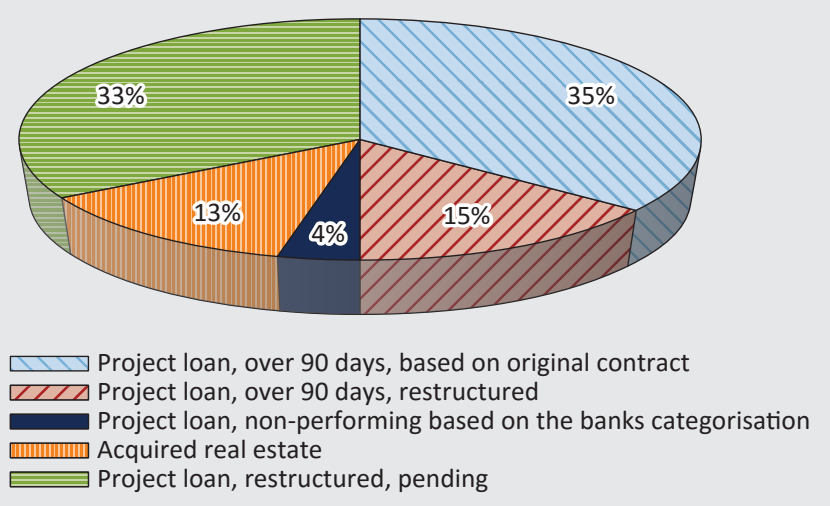

Source: MNB 
In addition to the delinquency and restructured nature of the transactions, it is also worth examining the type of real estate securing the problem project loans and repossessed collaterals. Based on the database, in this respect it is the office and shopping mall collaterals that should be flagged: of the total problem project exposures amounting to roughly HUF 700 billion, almost HUF 280 billion was linked to these types of real estate at the end of 2015 Q3 (Figure 3), i.e. roughly 40 per cent of the problem exposures. In addition, it is also worth mentioning the relatively high ratio of building site financing, as almost 15 per cent of the problem project loan portfolio was secured by such real estate.

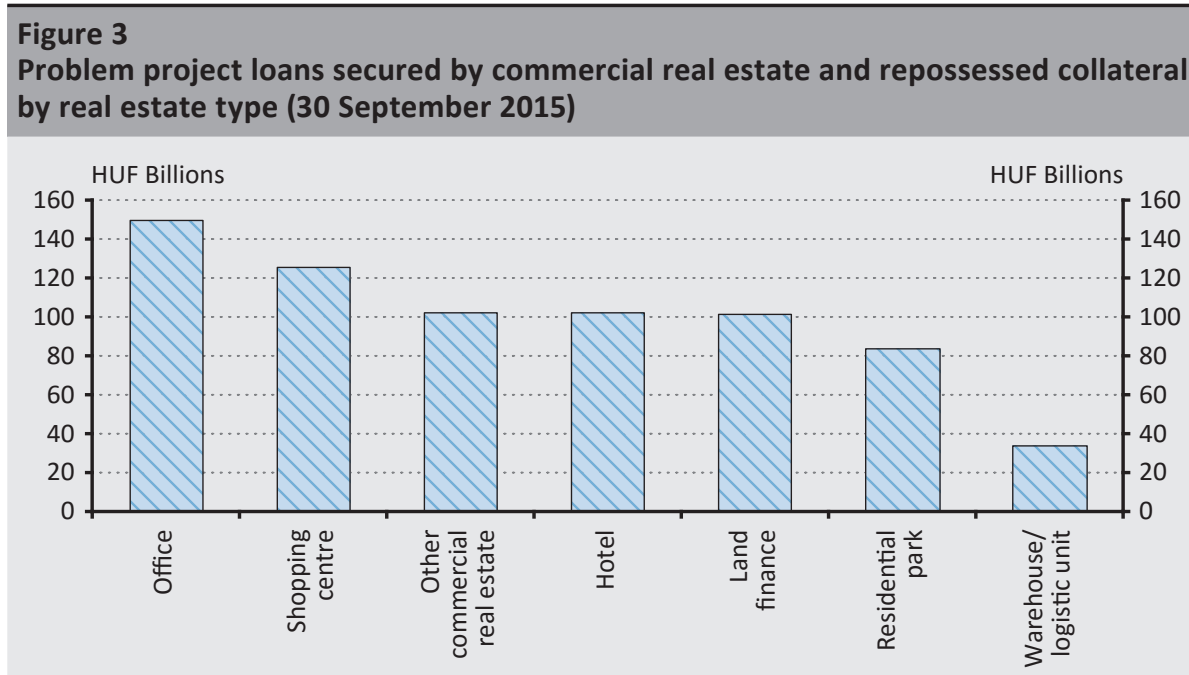

Source: $M N B$

As mentioned earlier, the cash flow generating capacity of project loans is of key importance for the probability of default. Roughly 75 per cent of the problem portfolio outstanding at the end of 2015 Q3 had any kind of cash flow generating capacity, and a bit more than half of this portfolio was able to pay interest in accordance with the contract, which may have been amended several times due to restructuring. As regards the principal instalment, the situation was much worse: roughly one third of the problem portfolio was not able to pay any principal instalment stipulated in the contract. Finally, we also examined the problem project exposure by denomination. In accordance with the pre-crisis practice, the vast majority, i.e. roughly two-thirds, of the problem portfolio was denominated in foreign currency at the end of 2015 Q3. Of that, the ratio of euro was two thirds, while most of the remaining part was denominated in Swiss franc. 


\section{Prescribing the systemic risk buffer}

As mentioned earlier, according to the MNB's assessment, the large portfolio of non-performing project loans entailed a special financial stability risk, not only due to the size and concentration of the portfolio, but also due to the extremely poor demand for the purchase of real estate and project receivables, since due to this it is more complicated for banks to clean their portfolio. Moreover, multiple restructuring ("evergreening") of these loans is particularly typical, since banks use this to try to conceal the real risks of the problem portfolio. Accordingly, with a view to strengthening the stability of the Hungarian banking system and reducing systemic risks, the MNB - in its capacity as macroprudential authority - opted for the introduction of the systemic risk buffer. The prescription of this buffer, as a potential macroprudential instrument encouraging the reduction of non-performing project loans, may stimulate the cleaning process.

Both demand and supply incentives may arise with a view to accelerating the portfolio cleaning process. Of the demand incentives, one of the most important could be the establishment of an asset management company for corporate loans, and particularly for project loans, which is able to take over the problem exposures relatively quickly and, in addition, may also stimulate the workout market. A good example of this could be the role of MARK Zrt, the appearance of which may have acted as an important catalyst both on the commercial real estate market and the project workout market on the demand side. It may also be regarded as a demand stimulating factor that, within the framework of Funding for Growth Scheme (FGS), the central bank permitted the purchase - for the purpose of lease - of commercial real estate securing non-performing or already cancelled loans, since in this way a financing constraint may be partially eased and it may generate additional demand for these assets. Thus, these two initiatives essentially impacted the demand side: MARK Zrt. appeared directly, as a buyer, on the market of problem project loans, thereby supporting portfolio cleaning by the banks, while at FGS the financing, at low cost, of the purchase of collaterals underlying problem loans may have assisted buyers and thereby the cleaning process.

In addition to the demand stimulating factors, incentives strengthening supply may also arise. The authorities of certain countries, and the ECB - operating as the banking supervision of the euro area - tightened, also for this purpose, the requirements pertaining to impairment provisioning, and the various capital requirement rules may also act as incentives to the supply of problem exposures. In this paper we essentially deal with the circumstances and impacts of the application of systemic risk buffer, focusing primarily on the cleaning of non-performing project loans. 


\subsection{Regulation of the systemic risk buffer}

Based on the European regulation effective from 2014, ${ }^{12}$ the competent authorities of all Member States may prescribe a systemic risk buffer for the credit institution sector, or for one or several sub-segments of the sector, in addition to the minimum capital requirement as part of the combined buffer requirement. ${ }^{13}$ This is possible where there is a need to prevent or reduce non-cyclical systemic risks or increase the resilience of the financial intermediary system. ${ }^{14}$ In Hungary, based on the rules stipulated in the Credit Institutions Act for prescribing the SRB, this is the competence of the MNB, supported by macroprudential instruments, in accordance with the following principles: ${ }^{15}$

- The rate may be set between 1 and 3 per cent, in steps of 0.5 per cent, but a higher rate may also be prescribed in particularly justified cases.

- When the buffer rate exceeds 3 per cent, the approval of the European Commission - formulated on the basis of the opinion of European Banking Authority (EBA) and European Systemic Risk Board (ESRB) - is needed, while below that Member States only have notification obligation (ESRB notification). ${ }^{16}$

- The capital buffer must be met with CET1 capital, for exposures to counterparties in Hungary, in European Economic Area (EEA) states and in third countries.

- The credit institution must recognise it on an individual, sub-consolidated or consolidated basis, but for institutions subject to consolidated supervision compliance on both an individual and consolidated basis may be prescribed.

- The buffer rate must be defined in such a way that it may not entail a disproportionate negative impact at the national or EU level (it must not jeopardise the functioning of internal market).

- Buffer rates must be reviewed at least every two years.

\subsection{Application of the systemic risk buffer to address the systemic risk arising in connection with project loans secured by commercial real estate}

Initially, banks had to comply with the new macroprudential capital buffer requirements from 1 January 2017, ${ }^{17}$ with this date later postponed by an amendment to 1 July $2017 .{ }^{18}$ Thus, the respective market participants had a relatively long adjustment

\footnotetext{
12 Article 133 (1) of Directive 2013/36/EU (CRDIV).

${ }^{13}$ The combined buffer requirement comprises, in addition to SRB, the capital conservation buffer, the countercyclical capital buffer, the G-SII buffer and the O-SII buffer.

${ }^{14}$ Article 35/A (1) of Act CXXXIX of 2013 on the Magyar Nemzeti Bank, 16 September 2013.

${ }^{15}$ Act CXXXIX of 2013 on the Magyar Nemzeti Bank, 16 September 2013.

${ }^{16} \mathrm{http}$ ://www.esrb.europa.eu/pub/pdf/2014-01-27-Decision_ESRB_2014-2_SRB.pdf?91f4fd3697b23924ebd9da0c3e923ae4

${ }^{17}$ https://www.mnb.hu/sajtoszoba/sajtokozlemenyek/2015-evi-sajtokozlemenyek/a-problemasprojekthitelekbol-eredo-kockazatok-kezelesere-az-mnb-rendszerkockazati-tokepuffert-vezet-be

18 https://www.mnb.hu/sajtoszoba/sajtokozlemenyek/2016-evi-sajtokozlemenyek/az-mnb-a-hitelezestamogatasa-erdekeben-tobb-idot-biztosit-a-banki-tokepufferek-megkepzesere
} 
period to clean the problem project exposures or, if portfolio cleaning failed, to comply with the capital buffer requirements. The systemic risk buffer could be suitably applied to encourage the institutions to clean the stuck, non-performing project loan portfolio from the balance sheet (by writing off or selling the non-performing portfolios). This was because this macroprudential instrument - in contrast to the tightening of impairment rules - acts as an incentive through the increased capital requirement due to the higher cost of capital. Practically this means that although upon tightening the impairment rules the institutions must recognise higher impairment loss, later on they may reverse it or part of it, if they sell the exposure at a higher price even years later. Accordingly, there is less motivation for portfolio cleaning to be implemented within a shorter time, since the cost of keeping the problem exposure in the balance sheet is relatively low. By contrast, upon prescribing the systemic risk buffer, keeping the problem exposure in the balance sheet for a longer period is already more expensive due to the cost of capital arising from the additional capital requirement. Prior to its implementation in Hungary, the application and calibration of the systemic risk buffer to encourage portfolio cleaning was unprecedented at the international level, while there were examples of other regulatory interventions to stimulate portfolio cleaning: for example, in the early 2000s in Japan it was mandatory to clean the balance sheet within three years from the default of the non-performing loans (a grace period of 2 years was specified for the outstanding portfolio), while in Brazil the worst quality loans must be written off within 6 months (IMF 2013).

The systemic risk buffers applicable to individual institutions or banking groups were prescribed in the form of individual MNB decisions on a consolidated basis. The rate of the capital buffer was determined on the basis of the credit institutions' individual contribution to the systemic risk, i.e. it was imposed in proportion to the domestic problem project loans and repossessed collaterals. The rate depended on the ratio of the gross amount of the problem exposures (i.e. loans non-performing for more than 90 days, the non-problem-free restructured project loans and other transactions, classified by the credit institution as non-performing not reduced by impairment) at a respective institution or banking group, to the domestic Pillar I capital requirement. If this balance exceeded 30 per cent of the capital requirement and HUF 5 billion, the systemic risk buffer was prescribed at least at 1 per cent, but could not exceed 2 per cent ${ }^{19}$ (Table 1). The application of gross exposure is important because in this way the respective institutions cannot decrease their calibration ratio by impairment provisioning, i.e. the indicator, which determined the rate of the capital buffer, may only be reduced by true sales of the exposures which remove them from the balance sheet.

The MNB passed the individual decisions determining the rate of the systemic risk buffer for the first time in 2017 Q2, based on the data for 2017 Q1. Based on

\footnotetext{
${ }^{19} \mathrm{https}: / /$ www.mnb.hu/letoltes/srb-altalanos-hatarozat-hu-20161024.pdf
} 
such, the systemic risk buffer had to be recognised from 1 July 2017. The individual regulatory decisions, which determined the rate of the systemic risk buffer to be recognised by credit institutions and credit institution groups, were reviewed annually on the basis of the dedicated reporting introduced, in accordance with the general decision (up to now, there were two reviews, in 2018 and 2019).

\begin{tabular}{|c|c|}
\hline \multicolumn{2}{|l|}{$\begin{array}{l}\text { Table } 1 \\
\text { Calibration of the systemic risk buffer }\end{array}$} \\
\hline $\begin{array}{l}\text { Problem project loan portfolio as a proportion } \\
\text { of the domestic Pillar I capital requirement }\end{array}$ & Systemic risk buffer \\
\hline $0.00-29.99 \%$ & $+0.0 \%$ \\
\hline $30.00-59.99 \%$ & $+1.0 \%$ \\
\hline $60.00-89.99 \%$ & $+1.5 \%$ \\
\hline above $90.00 \%$ & $+2.0 \%$ \\
\hline
\end{tabular}

\section{Adjustment by credit institutions after announcement of the systemic risk buffer requirement}

As mentioned earlier, by raising the capital requirement, the systemic risk buffer may be essentially suitable to encourage institutions to clean the non-performing project loans portfolios from the balance sheet. The capital buffer affects not only the distribution of costs over time, but - via the raised capital requirement - also the higher cost of capital, thereby encouraging institutions to perform cleaning. However, prior to its implementation in Hungary, application of the systemic risk buffer for the stimulation of portfolio cleaning was unprecedented, and thus it is worth examining the effect of this macroprudential instrument on the cleaning practice of the respective institutions.

In the first part of this section, within the framework of a descriptive analysis, we present the changes in the problem project loans and the portfolio cleaning process. Unfortunately, the database available to us and the special features of the market do not facilitate the application of econometrics - in an ideal case, the differencein-differences - methods to establish whether the cleaning process was stronger in the institutions theoretically affected by the macroprudential instrument. The main reason for this is that project loans were concentrated at relatively few banks, and thus our estimates may be distorted due to the low number of institutions (this does not permit the formation of convincing treatment control groups). In spite of this, we believe that a sufficiently comprehensive view of the cleaning process across the banking sector can be obtained by applying the descriptive analysis as well. In the second part of the section, we focus only on the affected banks: we examine in more detail the cleaning practice of the institutions affected by the capital buffer. Using the probit and linear probability model (LPM) estimates, we try to identify 
how certain factors of the problem project exposures (size, time elapsed since default, etc.) affected the probability of cleaning. ${ }^{20}$

\subsection{Portfolio cleaning process after announcement of the application of the systemic risk buffer}

Based on the data reviewed, following announcement of the systemic risk buffer requirement substantial portfolio cleaning was implemented for the problem project loans secured by commercial real estate. Compared to the situation in 2015 Q3, immediately before publication of the general decision stipulating the framework for the new capital requirement and the calibration process in November 2015, the balance of problem exposures fell from roughly HUF 700 billion to HUF 241 billion by 2017 Q1, i.e. the reference date for determining the systemic risk buffer. If the systemic risk buffer had been introduced immediately in 2015 Q3, it would have affected 6 institutions of the larger banking actors in total, while in the end it was effectively prescribed only for two institutions, ${ }^{21}$ but even those performed significant portfolio cleaning.

Heterogeneity among the banks related to portfolio cleaning was rather strong, although it affected at least half of the problem exposures even at the least active banks. The cleaning typically took place in the form of market sales, gross receivable write-offs and enforcement of receivables, while at one institution portfolio transfer was also realised during resolution. ${ }^{22}$ Sales of problem exposures were also supported by the recovery of the commercial real estate market and the revival of the workout market, where MARK Zrt. may have acted as a catalyst. At a systemic level, the strongest portfolio cleaning was observed for loans denominated in Swiss franc and for the transactions secured by gated community and shopping malls, and it primarily affected non-performing project exposures and to a lesser degree the repossessed real estate stated in the balance sheet (MNB 2017).

In addition to the denomination and the type of the underlying real estate collateral of the project exposure, it is also worth examining whether institutions gave preference to smaller or larger project exposures in the course of cleaning. One argument for the former may be that it could be easier to sell packages of smaller exposures and demand may also be higher, while the argument for the sales of larger exposures may be the more significant decrease in the nominal problem portfolio when concluding one unit of transaction. As illustrated by Figure 4, the full sample was characterised by the latter: institutions typically sold larger transactions, since the cumulated distribution of the problem portfolios calculated on the basis of the exposure amount shifted to the left.

\footnotetext{
${ }^{20}$ For the descriptive statistics of the variable included in the samples of the probit and LPM-model, see the annex.

${ }^{21}$ https://www.mnb.hu/sajtoszoba/sajtokozlemenyek/2017-evi-sajtokozlemenyek/a-problemasprojekthitelekbol-eredo-kockazatok-kezelese-erdekeben-az-mnb-ket-bankra-rendszerkockazati-tokepuffertirt-elo

22 https://www.mnb.hu/sajtoszoba/sajtokozlemenyek/2015-evi-sajtokozlemenyek/rendben-zajlik-az-mkbbank-szanalasa
} 


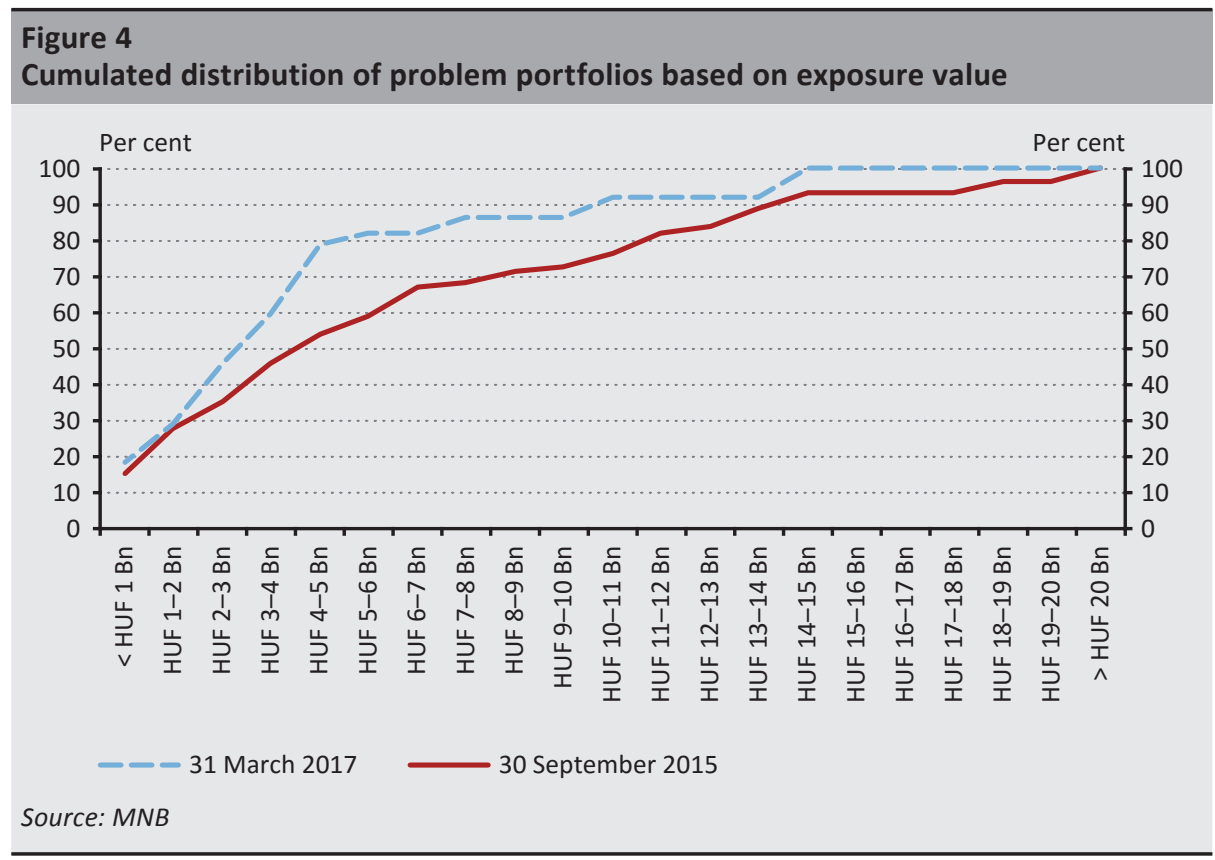

Relying on the available data, we also examined whether credit institutions are able to more quickly clean the exposures that are in default for a shorter time, and thus, in some sense, are of better quality. Presumably in parallel with the rise in the number of quarters elapsed since the default, the expected repayment ratio declines. As also illustrated by Figure 5, based on number of transactions in the 18 months after 30 September 2015, i.e. in the most intensive period of portfolio cleaning, institutions sold long overdue loans and loans overdue only for a few quarters in roughly the same proportion. Accepting the assumptions related to the expected ratio of repayment, according to a descriptive analyses we see no indication of institutions selecting problem loans that recently became delinquent, which presumably can be sold at better price, while keeping the worst problem assets in the balances sheet (the "cherry picking" hypothesis is also examined, among others, by Ciocchetta et al. 2017 in the cleaning practice of Italian banks).

Finally, we also examined whether portfolio cleaning was stronger at those institutions where - based on the 2015 Q3 data, i.e. immediately preceding the announcement of the application of the capital buffer - the systemic risk buffer would have been prescribed with a rate of at least 1 per cent. In these cases, more intensive cleaning was expected based on the motivating mechanism of the capital buffer, since maintaining the problem portfolio at the same level would have required these institutions to set aside a significant amount of additional capital. 


\section{Figure 5}

Number of quarters elapsed since the default of the problem project loans secured by real estate collateral and number of quarters elapsed after 30 September 2015 at the time of their cleaning

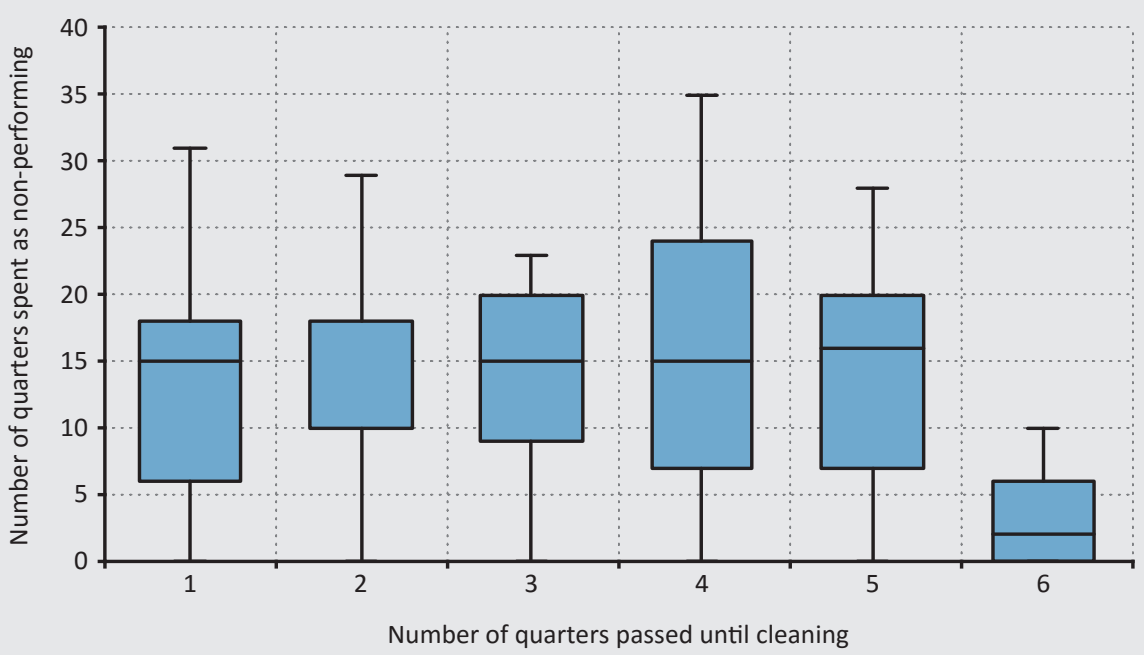

Note: We considered the period between 2015 Q3 and 2017 Q1, and thus banks had six quarters to clean their portfolios compared to 2015 Q3. Data points exceeding the upper or falling short of the lower quartiles by a value higher than one and a half times the interquartile interval value were eliminated as outliers.

Source: $M N B$

Our results indicate that stronger cleaning was observed at those institutions that would have been preliminarily affected by the systemic risk buffer (Figure 6). In the case of these institutions, based on the 2015 Q3 data, the gross balance of the problem exposures exceeded 30 per cent of the respective institution's domestic Pillar 1 capital requirement, and thus in the absence of additional balance sheet cleaning of adequate volume the individual systemic risk buffer requirement, at least at 1 per cent, would have been applicable to them as well (for the capital buffer level see the previous section). Following the preparation period, a systemic risk buffer rate other than zero applied to two credit institutions of the covered institutions, but even these institutions performed substantial balance sheet cleaning. It should be noted that the observed dynamics can also be recognised after the elimination of the portfolios affected by resolution; and at the institutions preliminarily affected by the capital buffer somewhat stronger portfolio cleaning was observed not only in nominal terms, but also in terms of ratios. 


\section{Figure 6 \\ Distribution of the problem exposures of credit institutions preliminarily affected and not affected by the systemic risk capital buffer as a percentage of the total problem exposures outstanding on 30 September 2015}

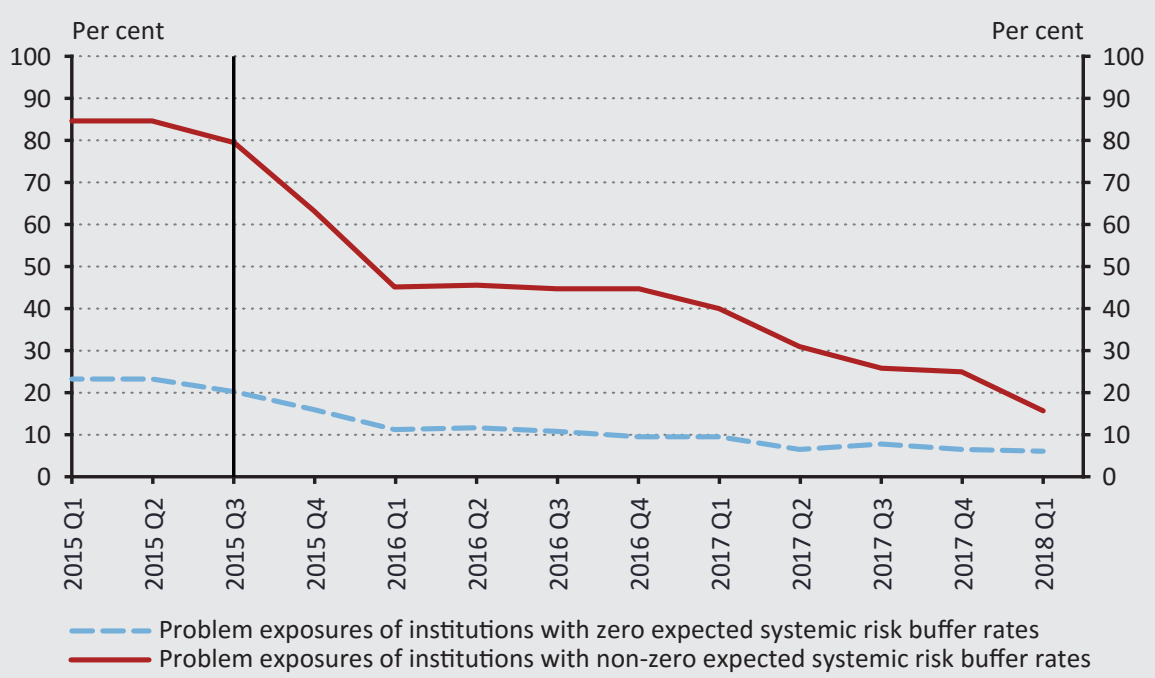

Note: Ignoring the portfolios affected by resolution. Portfolio outstanding on 30 September $2015=100$ per cent.

Source: $M N B$

\subsection{Cleaning practices of institutions initially affected by the capital buffer}

In order to examine our hypotheses for describing the adjustment by credit institutions preliminarily affected by the capital buffer, we performed probit and linear probability model estimations using the following specifications (D stands for the dummy variables). We run cross-sectional regression estimations on the problem exposure observations outstanding in 2015 Q3, which - based on the systemic risk buffer calibration rules and the problem exposure portfolios at that time - were included in the balance sheets of banks facing capital buffer requirement other than zero. Thus, we examined the problem exposures of only those institutions, where - based on the 2015 Q3 data, i.e. immediately preceding the announcement of the application of the capital buffer - the systemic risk buffer would have been prescribed with a rate of at least 1 per cent. The binary dependent variable's value of 1 represents observations which the respective banks have already cleaned from their balance sheet by the end of 2017 Q1 (which is the real reference date for prescribing the capital buffer). Independent variables include the size of the problem exposures, expressed in their logarithmised gross value converted into forint. In our database, the value of the number of quarters elapsed since the default until 2015 Q3 is missing for a considerable amount of the observations, which reduces the number of observations that may be involved in the estimates compared to the number of elements in the population of all problem exposures reported by the banks affected by 
the systemic risk buffer requirement (Table 2). Dummy variables were specified for the fulfilment of the interest instalment and principal instalment (they represent partial and full performance in accordance with the contract, the reference observations pay no interest and/or principal debt due in the contract even partially), and for the type of the real estate (the reference type is the hotel, dummies represent the shopping mall, office, warehouses/logistics facilities, residential park, building site financing and other project real estate financing types). Finally, we also included the dummies, estimating the fixed effects, representing the identity of the banks included in the sample with a view to eliminating potential bank-specific, one-off effects.

Probit model specification:

$\operatorname{Pr}($ Cleaned $=1 \mid \boldsymbol{X})$

$=\phi$ (constant $+\beta_{1} \log$ (exposure size) $+\beta_{2}$ Number of quarters in default

$+\beta_{3} D$ (Partial principal instalment $)+\beta_{4} D$ (Principal instalment in accordance with the contract $)+\beta_{5} D$ (Partial interest payment $)+\beta_{6} D$ (Interest payment in accordance with the contract) $+\left[\beta_{7} \ldots \beta_{12}\right] D$ (Type of the real estate dummies) $+\left[\beta_{13} \ldots \beta_{17}\right] D$ (Individual bank dummies $\left.)+\varepsilon_{i}\right)$

Linear model specification (LPM):

$D($ Cleaned $)=$ constant $+\beta_{1} \log$ (exposure size $)+\beta_{2}$ Number of quarters in default $+\beta_{3} D$ (Partial principal instalment $)+\beta_{4} D$ (Principal instalment in accordance with the contract $)+\beta_{5} D$ (Partial interest payment $)+\beta_{6} D$ (Interest payment in accordance with the contract $)+\left[\beta_{7} \ldots \beta_{12}\right] D$ (Type of the real estate dummies) $+\left[\beta_{13} \ldots \beta_{17}\right] D$ (Individual bank dummies) $+\varepsilon_{i}$

The results of the estimates are summarised in Table 2. When examining the size of exposures, we see that there is positive correlation between the size of the problem project exposures and the probability of their cleaning, at a significance level of 5 or 10 per cent, depending on the specification. Based on model specifications 2 and 4 which include control variables, we found that the size variable is less significant if the variables representing the type of collateral real estate is included. The coefficients of the variable of the number of months elapsed since the default are significantly positive under all specifications, i.e. they do not confirm the formerly mentioned empirical test hypotheses and outcomes, i.e. banks did not clean earlier the exposures that more recently became non-performing, but rather those exposures were removed from the balance sheet that became delinquent long ago. Similarly, a significant effect was observed in relation to principal instalment in accordance with the contract: the respective institutions were less likely to clean those problem project loans that were able to pay the principal instalments in accordance with the contract (also including principal instalments in accordance with the contract modified during restructuring). In relation to the probit estimation we also prepared the classification tables. Based on this, it can be stated that the model estimates in roughly 85 per cent correctly the cleaned status (cleaned vs. non-cleaned) of the 
problem exposures included in the sample at the institutions theoretically impacted by the systemic risk buffer (Table 3).

\section{Table 2 \\ Probit and LPM-model estimates with regard to the portfolio cleaning of problem project loans at the affected credit institutions}

\begin{tabular}{|c|c|c|c|c|}
\hline \multirow{3}{*}{ Independent variables } & \multicolumn{4}{|c|}{$\begin{array}{c}\text { Dependent variable Problem exposure cleaned by } 2017 \text { Q1= } 1 \\
\text { Non-cleaned problem exposure }=0\end{array}$} \\
\hline & \multicolumn{2}{|c|}{ Probit } & \multicolumn{2}{|c|}{ LPM } \\
\hline & Model 1 & Model 2 & Model 3 & Model 4 \\
\hline $\log$ (exposure size) & $\begin{array}{c}0.0360 * * * \\
(0.0126) \\
\end{array}$ & $\begin{array}{l}0.0187^{*} \\
(0.0102)\end{array}$ & $\begin{array}{c}0.0360 * * * \\
(0.0132) \\
\end{array}$ & $\begin{array}{c}0.0234 * * \\
(0.0117) \\
\end{array}$ \\
\hline $\begin{array}{l}\text { Number of } \\
\text { quarters in default }\end{array}$ & $\begin{array}{r}0.0189 * * * \\
(0.00238)\end{array}$ & $\begin{array}{c}0.0104 * * * \\
(0.0025)\end{array}$ & $\begin{array}{c}0.0188^{* * *} \\
(0.0027)\end{array}$ & $\begin{array}{c}0.0113^{* * *} \\
(0.0027)\end{array}$ \\
\hline \multicolumn{5}{|l|}{ Principal instalment } \\
\hline partial & & $\begin{array}{l}-0.029 \\
(0.101)\end{array}$ & & $\begin{array}{l}-0.070 \\
(0.098)\end{array}$ \\
\hline in accordance with the contract & & $\begin{array}{c}-0.334 * * * \\
(0.106) \\
\end{array}$ & & $\begin{array}{c}-0.329 * * * \\
(0.100) \\
\end{array}$ \\
\hline \multicolumn{5}{|l|}{ Interest payment } \\
\hline partial & & $\begin{array}{l}-0.0034 \\
(0,0875)\end{array}$ & & $\begin{array}{c}0.0312 \\
(0.0915) \\
\end{array}$ \\
\hline in accordance with the contract & & $\begin{array}{c}0.0442 \\
(0.0603)\end{array}$ & & $\begin{array}{c}0.0343 \\
(0.0714)\end{array}$ \\
\hline \multicolumn{5}{|c|}{ Type of collateral real estate securing the problem exposure } \\
\hline shopping mall & & $\begin{array}{c}-0.0796 \\
(0.086) \\
\end{array}$ & & $\begin{array}{l}-0.0504 \\
(0.0932)\end{array}$ \\
\hline office & & $\begin{array}{c}0.0722 \\
(0.0606) \\
\end{array}$ & & $\begin{array}{c}0.0793 \\
(0.0678) \\
\end{array}$ \\
\hline warehouses/logistics facilities & & $\begin{array}{c}-0.1802 * \\
(0.0956)\end{array}$ & & $\begin{array}{c}-0.1885^{*} \\
(0.1043)\end{array}$ \\
\hline residential park & & $\begin{array}{l}-0.0204 \\
(0.0725) \\
\end{array}$ & & $\begin{array}{c}0.000 \\
(0.0753) \\
\end{array}$ \\
\hline building site financing & & $\begin{array}{l}-0.1201 \\
(0.0869) \\
\end{array}$ & & $\begin{array}{c}-0.101 \\
(0.0781) \\
\end{array}$ \\
\hline other project real estate financing & & $\begin{array}{c}-0.583 * * * \\
(0.0632)\end{array}$ & & $\begin{array}{c}-0.549 * * * \\
(0.0623)\end{array}$ \\
\hline \multicolumn{5}{|c|}{ All specifications contain individual bank dummy variables } \\
\hline Constant (coefficient) & $\begin{array}{c}-2.309 * * \\
(0.906) \\
\end{array}$ & $\begin{array}{c}-0.12 \\
(1.168) \\
\end{array}$ & $\begin{array}{l}-0.164 \\
(0.275) \\
\end{array}$ & $\begin{array}{c}0.427 \\
(0.262) \\
\end{array}$ \\
\hline Number of observations & 414 & 414 & 414 & 414 \\
\hline $\begin{array}{l}\text { Pseudo } R(1-2) \text { or } \\
\text { R-square (3-4) }\end{array}$ & 0.21 & 0.46 & 0.26 & 0.5 \\
\hline
\end{tabular}

Note: The cross-sectional models are estimated on data from 2015 Q3, involving those banks for which the systemic risk buffer regulation would have prescribed a capital buffer higher than zero, calibrated on the basis of their problem exposure outstanding on that date. Below a zero value for the dummy variables representing the fulfilment of principal and interest instalment the observation is non-payer. Below a zero value for the dummy variables representing the type of the real estate, the real estate type is hotel. In the probit models, we present the average marginal effects, except for the constant. Standard errors in brackets. $* * * p<0.01 ; * * p<0.05 ; * p<0.1$. 


\begin{tabular}{|c|c|c|}
\hline \multicolumn{3}{|c|}{$\begin{array}{l}\text { Table } 3 \\
\text { Classification table of the probit estimation }\end{array}$} \\
\hline \multicolumn{3}{|c|}{ Classification table of Model 2} \\
\hline \multirow{2}{*}{$\begin{array}{l}\text { Did the bank clean the } \\
\text { problem exposure based on } \\
\text { the model's estimate? }\end{array}$} & \multicolumn{2}{|c|}{$\begin{array}{l}\text { Did the bank clean the problem exposure according to the } \\
\text { observations? }\end{array}$} \\
\hline & Cleaned & Did not clean \\
\hline Estimated cleaning & $87.65 \%(213)$ & $18.13 \%(31)$ \\
\hline $\begin{array}{l}\text { No cleaning according to the } \\
\text { estimate }\end{array}$ & $12.35 \%(30)$ & $81.87 \%(140)$ \\
\hline \multicolumn{3}{|c|}{$\begin{array}{l}\text { Note: Based on the backcasting, the model correctly estimates the cleaned status (cleaned vs. non-cle- } \\
\text { aned) of the problem exposures included in the model at roughly } 85 \text { per cent. During the classification, } \\
\text { we considered an estimate given for the cleaning of a specific observation as estimated cleaning over } \\
\text { a probability margin of } 0.6 \text {, since roughly } 60 \text { per cent of the observations are indeed cleaned. The num- } \\
\text { bers of observations in the different classification categories are shown in brackets. }\end{array}$} \\
\hline
\end{tabular}

\section{Conclusions}

In our paper we examined how banks adjusted to the systemic risk buffer requirement, a macroprudential measure applied to manage the systemic risk arising in connection with non-performing project loans secured by commercial real estate. The MNB deemed the persistently large portfolio and institutional concentration of the problem project loans observed in the Hungarian banking sector to be a key macroprudential risk. With a view to managing the risk, the MNB introduced a systemic risk buffer, the rate of which has been specified as a proportion of the individual contribution to systemic risk. Banks had to comply with the new macroprudential capital buffer requirements starting from 1 July 2017, and thus the market participants in question had a relatively long adjustment period to clean the problem project exposures or, if portfolio cleaning failed, to comply with the capital buffer requirement. In this paper we essentially analysed the effects of this macroprudential intervention, relying on a micro-level database of the banking sector.

We reviewed the potential unfavourable effects of the large non-performing portfolio on the banking sector and the real economy and then presented the features of the non-performing project loan portfolio secured by commercial real estate, regarded as a systemic risk, both in terms of the type of the collateral real estate, the denomination of the loans and the cash flow generation capacity of the scheme. In respect of credit institutions' adjustment following announcement of the macroprudential measure, we found that cleaning typically took the form of market sales, write-offs of gross receivables and the enforcement of receivables. Examining the entire sample, we found that institutions typically sold the larger transactions, and based on the examined data there is no indication that the institutions selected problem loans that recently became delinquent and thus presumably can be sold 
at a better price, while they kept the worst-quality problem assets on the balance sheet. We also examined whether portfolio cleaning was stronger at institutions where - based on the 2015 Q3 data, i.e. immediately preceding the announcement of the application of the capital buffer - the systemic risk buffer would have been prescribed. Based on our results, it can be stated that a different cleaning trend was observed at the institutions which would have been preliminarily affected by the systemic risk buffer. The observed dynamics remain even after eliminating the portfolios affected by resolution. In the final part of our paper, we perform a more thorough examination of the cleaning practice of the institutions preliminarily affected by the capital buffer. Relying on the probit and linear probability model estimates, we tried to identify how certain factors of the problem project exposures (size, time elapsed since default, etc.) affected the probability of their cleaning. When examining the size of exposures, we find that there is positive correlation between the size of the problem project exposures and the probability of their cleaning, although when involving the variable of the collateral real estate types the size variable is less significant. The coefficients of the variable for the number of months elapsed since default are significantly positive under all specifications, i.e. they do not confirm the formerly mentioned empirical test hypotheses and outcomes, and thus banks did not clean earlier the exposures that more recently defaulted, but rather those exposures were removed from the balance sheet that defaulted long ago. Similarly, a significant effect is observed in relation to the principal instalment in accordance with the contract: the institutions were less likely to clean those problem project loans that were able to perform principal instalment in accordance with the contract.

\section{References}

Accornero, M. - Alessandri, P. - Carpinelli, L. - Sorrentino, A.M. (2017): Non-performing loans and the supply of bank credit: evidence from Italy. Banca d'Italia Occasional Papers No. 374, March. https://doi.org/10.2139/ssrn.2954995

Aiyar, S. - Bergthaler, W. - Garrido, J.M. - Ilyina, A. - Jobst, A. - Kang, K. - Kovtun, D. - Liu, Y. - Monaghan, D. - Moretti, M. (2015): A Strategy for Resolving Europe's Problem Loans. IMF SDN/15/19, September. https://doi.org/10.5089/9781513591278.006

Angelini, P. (2018): Do high levels of NPLs impair banks credit allocation. Banca d'Italia Notes on Financial Stability and Supervision No. 12, April. https://www.bancaditalia. it/pubblicazioni/note-stabilita/2017-0012/index.html?com.dotmarketing.htmlpage. language=1. Downloaded: 11 December 2018.

Asriyan, V. - Laeven, L. - Martín, A. (2018): Collateral Booms and Information Depletion. CEPR Discussion Papers 13340, November. https://doi.org/10.2139/ssrn.3287948 
Balgova, M. - Nies, M. - Plekhanov, A. (2016): The economic impact of reducing nonperforming loans. EBRD Working Paper, No. 193, October. https://doi.org/10.2139/ssrn.3119677

Baudino, P. - Yun, H. (2017): Resolution of non-performing loans - policy options. BIS Financial Stability Institute, FSI Insights on policy implementation, No. 7, April.

Baudino, P. - Orlandi, J. - Zamil, R. (2018): The identification and measurement of nonperforming assets: a cross-country comparison. BIS Financial Stability Institute, FSI Insights on policy implementation, No. 7, April.

Bending, T. - Berndt, M. - Betz, F. - Brutscher, P. - Nelvin, O. - Revoltella, D. - Slacik, T. Wolski, M. (2014): Unlocking lending in Europe. European Investment Bank, October. http://www.eib.org/en/infocentre/publications/all/unlocking-lending-in-europe.htm. Downloaded: 25 February 2019.

Berger, A.N. - Young, De R. (1995): Problem loans and cost efficiency in commercial banks. Journal of Banking \& Finance, 21(6): 849-870. https://doi.org/10.1016/S03784266(97)00003-4

Berti, K. - Engelen, C. - Vasicek, B. (2017): A macroeconomic perspective on non-performing loans (NPLS). Quarterly Report on the Euro Area (QREA), Directorate General Economic and Financial Affairs (DG ECFIN), European Commission, 16(1): 7-21.

Bethlendi, A. (2007): A hazai bankok hitelezésiveszteség-elszámolásának vizsgálata (Review of credit loss recognition by Hungarian banks). Közgazdasági Szemle (Economic Review), 54(January): 67-93.

Bredl, S. (2017): The role of non-performing loans in the transmission of monetary policy. Unpublished paper; presented at the conference of the National Bank of Belgium entitled "Fifth Research Workshop of the MPC Task Force on Banking Analysis for Monetary Policy". https://www.nbb.be/doc/ts/enterprise/conferences/mpc-taskforce-2018/0102a-sebastian_bredl_paper.pdf. Downloaded: 12 December 2018.

Bushman, R.M. - Williams, C.D. (2015): Delayed Expected Loss Recognition and the Risk Profile of Banks. Journal of Accounting Research, 53(3): 511-553. https://doi. org/10.1111/1475-679X.12079

Ciocchetta, F. - Conti, F.M. - De Luca, R. - Guida, I. - Rendina, A. - Santini, G. (2017): Bad loan recovery rates. Banca d'Italia Notes on Financial Stability and Supervision No. 12, January. https://www.bancaditalia.it/pubblicazioni/note-stabilita/2017-0007/en_Note_di_stabilita_ finanziaria_e_vigilanza_N._7.PDF?language_id=1. Downloaded: 10 December 2018.

Cohen, B.H. - Edwards, G.A. (2017): (2017): The new era of expected credit loss provisioning. BIS Quarterly Review, 2017(March): 39-56. 
Constâncio, V. (2017): Resolving Europe's NPL burden: challenges and benefits. Presentation at the conference entitled "Tackling Europe's non-performing loans crisis: restructuring debt, reviving growth", organised by Bruegel. https://www.ecb.europa.eu/press/key/ date/2017/html/sp170203.en.html. Downloaded: 12 December 2018.

Dinger, V. - Vallascas, F. (2016): Do Banks Issue Equity When They Are Poorly Capitalized? Journal of Financial and Quantitative Analysis, 51(5): 1575-1609. https://doi.org/10.1017/ S0022109016000545

EC (2017): Council conclusions on Action plan to tackle non-performing loans in Europe. European Council Press Release 459/17, 11 July. https://www.consilium.europa.eu/en/ press/press-releases/2017/07/11/conclusions-non-performing-loans/. Downloaded: 01 December 2018.

ECB (2017): Stocktake of national supervisory practices and legal frameworks related to NPLs. European Central Bank, June.

https://www.bankingsupervision.europa.eu/ecb/pub/pdf/ssm.stock_taking2017.en.pdf. Downloaded: 01 December 2018.

EP (2017): Report on Banking Union - Annual Report 2016. European Parliament Committee on Economic and Monetary Affairs, 2016/2247(INI), 2 February. http://www. europarl.europa.eu/sides/getDoc.do?pubRef=-//EP//NONSGML+REPORT+A8-20170019+0+DOC+PDF+VO//EN. Downloaded: 01 December 2018.

ESRB (2015): Report on commercial real estate and financial stability in the EU. European Systemic Risk Board, December. https://www.esrb.europa.eu/pub/pdf/other/2015-12-28_ ESRB_report_on_commercial_real_estate_and_financial_stability.pdf. Downloaded: 01 December 2018.

ESRB (2017): Resolving non-performing loans in Europe. European Systemic Risk Board, July https://www.esrb.europa.eu/pub/pdf/reports/20170711_resolving_npl_report.en.pdf. Downloaded: 01 December 2018.

Fell, J. - Grodzicki, M. - Martin, R. - O'Brien, E. (2016): Addressing market failures in the resolution of non-performing loans in the euro area, ECB Financial Stability Review, November. https://www.ecb.europa.eu/pub/pdf/other/sfbfinancialstabilityreview201611. en.pdf. Downloaded: 19 February 2019.

Fell, J. - Grodzicki, M. - Krušec, D. - Martin, R. - O’Brien, E. (2017): Overcoming non-performing loan market failures with transaction platforms. ECB Financial Stability Review, November. https://www.ecb.europa.eu/pub/pdf/other/ecb. sfafinancialstabilityreview201711.en.pdf?dc45e3fbcd9702405c91bf3e5f491787. Downloaded: 10 December 2018. 
Gandrud, C. - Hallerberg, M. (2017): How not to create zombie banks: lessons for Italy from Japan. Bruegel Policy Contribution 6/17.

http://bruegel.org/wp-content/uploads/2017/03/PC-06-2017-030317.pdf. Downloaded: 13 December 2018.

Gangeri, M. - Lanotte, M. - Della Corte, G. - Rinna, G. (2017): Why exceptional NPLs sales should not affect the estimated LGDs of A-IRB banks. Banca d'Italia Notes on Financial Stability and Supervision No. 12, January 12. https://www.bancaditalia.it/pubblicazioni/ note-stabilita/2017-0006/index.html?com.dotmarketing. htmlpage.language=1. Downloaded: 14 December 2018.

Ghosh, A. (2017): Sector-specific analysis of non-performing loans in the US banking system and their macroeconomic impact. Journal of Economics and Business, 93(C): 29-45. https://doi.org/10.1016/j.jeconbus.2017.06.002

Gropp, R. - Vesala, J. (2004): Deposit insurance, moral hazard and market monitoring. Review of Finance, 8(4): 571-602. https://doi.org/10.1093/rof/8.4.571

Homar, T. - Kick, H. - Salleo, C. (2015): What drives forbearance-evidence from the ECB Comprehensive Assessment. ECB Working Paper Series, No. October 1860.

https://www.ecb.europa.eu/pub/pdf/scpwps/ecbwp1860.en.pdf?a48b193641e0da 152445946749510632. Downloaded: 10 December 2018.

IMF (2013). IMF Country Report No. 13/299, 6 September. http://www.imf.org/external/ pubs/ft/scr/2013/cr13299.pdf. Downloaded: 10 December 2018.

IMF (2015). A Strategy for Resolving Europe's Problem Loans, Technical Background Notes. IMF Staff Discussion Notes, No. 15/19, 6 September. https://www.imf.org/en/Publications/ Staff-Discussion-Notes/Issues/2016/12/31/A-Strategy-for-Resolving-Europe-s-ProblemLoans-43286. Downloaded: 25 February 2019.

Jassaud, N. - Kang K.H. (2015): A Strategy for Developing a Market for Nonperforming Loans in Italy. IMF Working Paper 2015/24. https://doi.org/10.5089/9781498337984.001

Kirti, D. (2017): When Gambling for Resurrection is Too Risky. IMF Working Paper 17/180, August. https://doi.org/10.5089/9781484312667.001

Li, Y. (2017): Peer effect in bank financial reporting: evidence from loan loss provision. Ph.D Thesis, National University of Singapore, April. http://scholarbank.nus.edu.sg/ handle/10635/136268. Downloaded: 25 February 2019.

Louzis, D.P. - Vouldis, A.T. - Metaxas, V.L. (2012): Macroeconomic and bank-specific determinants of non-performing loans in Greece a comparative study of mortgage, business and consumer loan portfolios. Journal of Banking \& Finance, 36(4): 1012-1027. https://doi.org/10.1016/j.jbankfin.2011.10.012 
MNB (2015): Financial Stability Report. Magyar Nemzeti Bank, November. https://www.mnb. hu/letoltes/stabilitasi-jelentes-2015-november-eng.pdf. Downloaded: 12 January 2019.

MNB (2017): Macroprudential report 2017. Magyar Nemzeti Bank, December https://www. mnb.hu/letoltes/makroprudencialis-jelentes-eng.pdf. Downloaded: 12 December 2018.

Navaretti, G.B. - Calzolari, G. - Pozzolo, A.F. (2017): Getting Rid of NPLs in Europe. European Economy 2017 Vol. 1, June. http://bruegel.org/wp-content/uploads/2017/07/European_ Economy_2017_1_v1.pdf. Downloaded: 25 February 2019.

Occhino, P. (2010): Is Debt Overhang Causing Firms to Underinvest? Federal Reserve Bank of Cleveland, Economic Commentary, July. https://www.clevelandfed.org/newsroomand-events/publications/economic-commentary/economic-commentary-archives/2010economic-commentaries/ec-201007-is-debt-overhang-causing-firms-to-underinvest.aspx. Downloaded: 10 December 2018.

Olszak, M. - Pipień, M. - Kowalska, I. - Roszkowska, S. (2017): What Drives Heterogeneity of Cyclicality of Loan-Loss Provisions in the EU? Journal of Financial Services Research, 51(1): 55-96. https://doi.org/10.1007/s10693-015-0238-6

Peek, J. - Rosengren, E.S. (2005): Unnatural Selection: Perverse Incentives and the Misallocation of Credit in Japan. The American Economic Review, 95(4): 1144-1166. https://doi.org/10.1257/0002828054825691

Philippon, T. (2009): The Macroeconomics of Debt Overhang. Paper presented at the conference, organised by IMF, entitled "10th Jacques Polak Annual Research Conference" Washington, DC, 5-6 November. https://www.imf.org/external/np/res/seminars/2009/ arc/pdf/Philippon.pdf. Downloaded: 10 December 2018.

Schiantarelli, F. - Stacchini, M. - Strahanz, P.E. (2016): Bank Quality, Judicial Efficiency and Borrower Runs Loan Repayment Delays in Italy. NBER Working Paper No. 22034, August. https://doi.org/10.2139/ssrn.2733535

Stolz, S.M. (2002): The Relationship between Bank Capital, Risk-Taking, and Capital Regulation: A Review of the Literature. Kiel Working Papers No. 1105, Kiel Institute for the World Economy (IfW), February. https://www.econstor.eu/bitstream/10419/17759/1/ kap1105.pdf. Downloaded: 25 February 2019.

Storz, M. - Koetter, M. - Setzer, R. - Westphal, A. (2017): Do we want these two to tango? On zombie firms and stressed banks in Europe. ECB Working Paper Series, No. October 2104. https://www.ecb.europa.eu/pub/pdf/scpwps/ecb.wp2104. en.pdf?0167b3eada64c9757df8e6e0b866b3a1. Downloaded: 10 December 2018. 
Suárez, J. - Serrano, A.S. (2018): Approaching non-performing loans from a macroprudential angle. Reports of the Advisory Scientific Committee, No. September 7.

https://www.esrb.europa.eu/pub/pdf/asc/esrb.asc181001_7_ApproachingNPLsmacro prudentialangle.en.pdf. Downloaded: 10 December 2018.

Szenes, M. - Tomsics, A. - Kutasi, D. (2017): Risks of Commercial Real Estate Financing Based on the Experiences of Supervisory Reviews. Financial and Economic Review, 16(1): 74-91. https://en-hitelintezetiszemle.mnb.hu/letoltes/mark-szenes-andras-tomsics-david-kutasi. pdf

Tarchouna, A. - Jarraya, B. - Bouri, A. (2017): How to explain non-performing loans by many corporate governance variables simultaneously? A corporate governance index is built to US commercial banks. Research in International Business and Finance, 42(December): 645-657. https://doi.org/10.1016/j.ribaf.2017.07.008 


\section{Annex}

\section{Descriptive statistics of the variables included in the samples of the probit and LPM model}

\begin{tabular}{l|c|c|c|c} 
& Average & $\begin{array}{l}\text { Standard } \\
\text { deviation }\end{array}$ & Lower quartile & Upper quartile \\
\hline $\begin{array}{l}\text { Gross exposure value (HUF), } \\
\text { logarithmised }\end{array}$ & 19.55 & 1.86 & 18.75 & 20.7 \\
\hline $\begin{array}{l}\text { Number of } \\
\text { quarters in default }\end{array}$ & 11.12 & 8.76 & 3 & 18 \\
\hline
\end{tabular}

Dummy variables

\section{Description}

Cleaned: Takes the value of 1, if the exposure that was a problem exposure in 2015 Q3

is removed from the bank's balance sheet or becomes performing by 2017 Q1

Observations belonging to the respective category (per cent)

Principal instalment

\begin{tabular}{l|c}
\hline Non-payer: benchmark observations in the estimates, no principal instalment is made & 56 \\
\hline $\begin{array}{l}\text { Partial: only partial payment of the principal instalment specified in the original } \\
\text { contract for the exposure }\end{array}$ & 34 \\
\hline $\begin{array}{l}\text { Full: full payment of the principal instalment specified in the original contract for the } \\
\text { exposure }\end{array}$ & 10 \\
\hline $\begin{array}{l}\text { Interest payment } \\
\text { Non-payer: benchmark observations in the estimates, no interest payment is made }\end{array}$ & 47 \\
\hline $\begin{array}{l}\text { Partial: only partial payment of the interest burden specified in the original contract } \\
\text { for the exposure }\end{array}$ & 20 \\
\hline $\begin{array}{l}\text { Full: full payment of the interest burden specified in the original contract for the } \\
\text { exposure }\end{array}$ & 33 \\
\hline
\end{tabular}

Type of collateral real estate securing the problem exposure

\begin{tabular}{l|c}
\hline Hotel: benchmark observations in the estimates & 12 \\
\hline Shopping mall & 6 \\
\hline Office & 19 \\
\hline Warehouses/logistics facilities & 4 \\
\hline Residential park & 18 \\
\hline Building site financing & 11 \\
\hline Other commercial real estate financing, property financing, project financing & 30 \\
\hline
\end{tabular}

Note: We applied fixed effects to the banks included in the sample. 